\title{
Electrochemical Reactivation of AISI 409 Ferritic Stainless Steel Sheet Welded by Laser Process with application in aeronautical
}

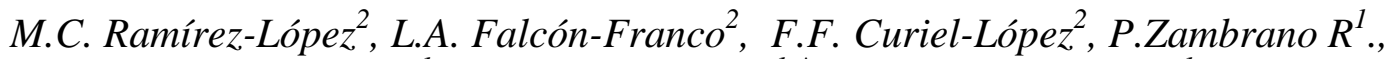 \\ J.A. Cabral-Miramontes ${ }^{1}$, C. Gaona-Tiburcio ${ }^{1},{ }^{*}$ F.Almeraya-Calderón ${ }^{1}$. \\ ${ }^{1}$ Universidad Autónoma de Nuevo León, UANL. Facultad de Ingeniería Mecánica y Eléctrica, FIME \\ Centro de Investigación e Innovación en Ingeniería Aeronáutica, CIIIA, Av. Universidad S/N. Ciudad \\ Universitaria. 66455 San Nicolás de los Garza, Nuevo León, México. \\ ${ }^{2}$ Universidad Autónoma de Coahuila. Facultad de Metalurgia, Carretera 57, Monclova, Coahuila. \\ *E-mail: falmeraya.uanl.ciiia@gmail.com
}

doi: $10.20964 / 2017.06 .38$

Received: 22 February 2017 / Accepted: 11 April 2017 / Published: 12 May 2017

\begin{abstract}
The susceptibility to sensitization in 409 ferritic stainless steel (FSS) weldments was studied, by means of double loop electrochemical potentiokinetic reactivation test (DL-EPR). After the electrochemical test, the microstructure was analyzed by scanning electron microscopy (SEM) and the presence of elements with dispersive energy of X-rays (EDS), with the X-ray diffraction (XRD) technique they were identified present phases in different welds. Microhardness profiles were employed to evaluate the mechanical properties. With the aim of analyze the effect on the degree of sensitization to welding processes and the base material, a methodological analysis of gas metal arc welding GMAW, gas tungsten arc welding GTAW and LASER welding process was performed. The LASER process generated the highest ratio between the reactivation (Ir) and activation (Ia) current, despite it caused less microstructural change. The higher ratio $\mathrm{Ir} / \mathrm{Ia}$ is attributed to the lack of penetration in the butt join, showing crevice corrosion.
\end{abstract}

Keywords: 409 Ferritic stainless steel, DL-EPR, GMAW, GTAW, LASER.

\section{$\underline{\text { FULL TEXT }}$}

(C) 2017 The Authors. Published by ESG (www.electrochemsci.org). This article is an open access article distributed under the terms and conditions of the Creative Commons Attribution license (http://creativecommons.org/licenses/by/4.0/). 